Relations industrielles

Industrial Relations

\title{
Index of volume 6
}

\section{0-1951}

Volume 6, numéro 4, septembre 1951

URI : https://id.erudit.org/iderudit/1023145ar

DOI : https://doi.org/10.7202/1023145ar

Aller au sommaire du numéro

Éditeur(s)

Département des relations industrielles de l’Université Laval

ISSN

0034-379X (imprimé)

1703-8138 (numérique)

Découvrir la revue

Citer ce document

(1951). Index of volume $6: 1950-1951$. Relations industrielles / Industrial

Relations, 6(4), 127-127. https://doi.org/10.7202/1023145ar

Tous droits réservés (C Département des relations industrielles de l’Université Laval, 1951

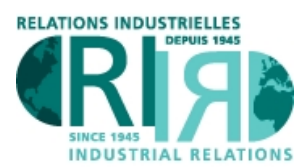

INDUSTRIAL. RELATION
Ce document est protégé par la loi sur le droit d'auteur. L'utilisation des services d'Érudit (y compris la reproduction) est assujettie à sa politique d'utilisation que vous pouvez consulter en ligne.

https://apropos.erudit.org/fr/usagers/politique-dutilisation/ 
Apprenticeship and Statistics - Charles-E. Thérien, No. 1, December 1950, p. 26.

Arbitration Statistics - No. 2, March 1951, p. 62.

Career Possibilities in Industrial Relations - No. 2, March 1951 , p. 59.

Comparative Study of the Legislation on Conciliation and Arbitration - Introduction, Canada, Province of Quebec, No. 1, December 1950, p. 11; United States of America, No. 2, March 1951, p. 52; United Kingdom, Free State of Ireland, No. 3, June 1951, p. 72; France, No. 4, September 1951, p. 115.

Conciliation of Labour Disputes (The) - I-Typical Cases, Jean-Paul Ferland; II-Conciliation from the Inside Viewpoint, Léopold Jasmin, No. 3, June 1951, p. 79.

Conciliation Staistics - No. 3, June 1951, p. 94.

Congress of the Professionnal Association of Industrialists (The) - Lionel Moreau, ptre, No. 1, December 1950, p. 28.

Employment and Unemployment in Quebec - Stanislas Picard, No. 3, June 1951, p. 92.

Forced Labour Camps in Countries under Communist Domination - Francois Brégha, No. 1, December 1950, p. 4; No. 2, March 1951, p. 48.

Guaranteed Wages in the Iron and Steel Industry - No. 1, December 1950 , p. 31 .

Industrial Relations Congress (Sixth) - No. 2, March 1951, p. 63.

Labour Jurisprudence - No. 1, December 1950, p. 29.

Labour Jurisprudence - Jean-H. Gagné, No. 4, September 1951 , p. 122.

Labour Relations Board a Judiciary Tribunal? (Is the) Me Marie-Louis Beaulieu, c.r., No. 1, December 1950, p. 23.

Recruiting, Selection and Placement of Building Trades Apprentices - Charles-E. Thérien, No. 3, June 1951, p. 84.

Security of the Workman's Family - No. 2, March 1951, p. 34 .

Social Doctrine of the Church and Economic Management of Enterprises - Rev. Gérard Dion, No. 4, September 1951 , p. 98.

Teamwork in Industry - Employer-Employee Production Committees - No. 4, September 1951, p. 117.

Toward a Union of Families - No. 3, June 1951, p. 89.

Trade Union Statistics - No. 1, December 1950, p. 30.

Vocational Training for Industrial Workers - Léonce Girard. No. 4, September 1951, p. 109.

"Welfare State" (The Concept of the) - Maurice Tremblay, No. 2, March 1951, p. 42.

"Welfare State" (The) - Economic Objectives and Financing - René Tremblay, No. 3, June 1951. p. 66.

When We grow Old... - Gérard Tremblay, No. 2, March 1951 , p. 35.

World-wide Economy (A) - Rev. Lionel Moreau, No. 3, June 1951 , p. 86. 